\title{
Comparison of Epidemics of Botrytis Fruit Rot and Powdery Mildew of Strawberry in Large Plastic Tunnel and Field Production Systems
}

\author{
C. L. Xiao, C. K. Chandler, J. F. Price, J. R. Duval, J. C. Mertely, and D. E. Legard, University of Florida, Gulf \\ Coast Research and Education Center, Dover 33527
}

\begin{abstract}
Xiao, C. L., Chandler, C. K., Price, J. F., Duval, J. R., Mertely, J. C., and Legard, D. E. 2001 Comparison of epidemics of Botrytis fruit rot and powdery mildew of strawberry in large plastic tunnel and field production systems. Plant Dis. 85:901-909.

Epidemics of Botrytis fruit rot (Botrytis cinerea) and powdery mildew (Sphaerotheca macularis f. sp. fragariae) in annual strawberry were compared in large plastic tunnel and field production systems during the 1998-99 and 1999-2000 seasons. Treatments were factorial combinations of two main plots (field and tunnel) and four subplots, including combinations of two cultivars (Camarosa and Sweet Charlie) and two captan schedules arranged in a split-plot design with three replications. The mean incidence of Botrytis fruit rot was 88 to $94 \%$ lower in tunnels than in the field. The incidence of Botrytis fruit rot for the untreated control in tunnels was less than $2 \%$, which was $89 \%$ lower than that of the 7-day captan schedule in the field. This indicates that Botrytis fruit rot can be controlled effectively without fungicides in a tunnel cultural system. Powdery mildew was severe on susceptible cultivar Camarosa in tunnels. Early season yields of cultivar Sweet Charlie were significantly higher in tunnels than in the field. Shorter periods of leaf wetness and higher temperatures in tunnels may have contributed to a lower incidence of Botrytis fruit rot and a higher incidence of powdery mildew on fruit in tunnels compared with open field plots.
\end{abstract}

Additional keywords: cultural control, epidemiology, gray mold, protected culture

Florida is the major winter fresh strawberry supplier for the eastern United States and Canada, with 2,400 ha of fruit production fields primarily in west-central Florida and an annual farm gate revenue of $\$ 160$ million in 1997-98. In Florida, strawberry plants are grown as an annual crop in a hill plasticulture system (1), which includes preplant soil fumigation with a mixture of methyl bromide and chloropicrin, raised beds with black plastic mulch, and drip irrigation. Bare-root transplants are set during October. Fruit harvest begins in November and may continue until April.

Botrytis fruit rot caused by Botrytis cinerea is the major limiting factor in strawberry production in Florida, causing preharvest losses of up to $15 \%$ of the fruit on susceptible cultivars, even with weekly applications of fungicides (7). Botrytis fruit rot is controlled by a combination of cultural and chemical methods. Although differences in susceptibility to Botrytis

Corresponding author: C. L. Xiao; current address: Washington State University, Tree Fruit Research and Extension Center, $1100 \mathrm{~N}$. Western Avenue, Wenatchee 98801

E-mail: clxiao@wsu.edu

Florida Agricultural Station Journal Series R07302 .

Accepted for publication 13 April 2001.

Publication no. D-2001-0604-03R

() 2001 The American Phytopathological Society fruit rot were observed recently among several commercial cultivars, none were highly resistant (9). Cultural practices such as the removal of senescent foliage and diseased fruit (11), use of wider plant spacing (9), and use of drip irrigation instead of overhead sprinkler irrigation $(1,18)$ have been used as supplemental measures to improve the control of Botrytis fruit rot. Because climatic conditions during the strawberry growing season in Florida are highly conducive to Botrytis fruit rot epidemics, control of the disease has been reliant largely on fungicides. Weekly application of captan has been a standard practice for the control of Botrytis fruit rot, and captan may be applied up to 24 times during a growing season.

Powdery mildew caused by Sphaerotheca macularis f. sp. fragariae occurs everywhere strawberries are grown. It mainly causes foliar damage, but also can infect fruit, especially on susceptible cultivars (6). Control of powdery mildew relies on the use of disease-free transplants in annual production systems and applications of protectant or systemic fungicides $(8,10)$. Currently, commercial cultivars of strawberry have varying levels of resistance to powdery mildew (12). Among the two most popular cultivars grown in Florida, Camarosa is highly susceptible to powdery mildew, whereas Sweet Charlie is more resistant to powdery mildew.

Protected culture in greenhouses and plastic tunnels is used widely for strawberry production in other countries $(3,15)$.
Plastic tunnels are the predominant strawberry production system used to force early fruit ripening and to protect fruit from unfavorable weather in France, Italy, and Spain (3). Reductions in the incidence of Botrytis have been observed on tomato and cucumber grown in the greenhouse (4). The effects of protected culture on Botrytis fruit rot development on strawberry, however, have not been studied extensively (6). Powdery mildew can be a problem under protected cultures $(6,10)$. Jordan and Hunter (6) observed a significantly higher level of powdery mildew on strawberry leaves under colored films than under clear film or glass, although little information is available on powdery mildew development on strawberry fruit in protected culture systems.

Public concerns over pesticide residues on fresh-market commodities led to new restrictions on the use of fungicides on strawberries. Additional regulations may be imposed by the Environmental Protection Agency or other regulatory agencies in the future. Therefore, it is prudent to develop disease management programs that have less of a dependence on fungicides for disease control.

In west-central Florida, frequent rains and long periods of leaf wetness occur during the strawberry growing season (9). Such weather is highly conducive to Botrytis fruit rot epidemics. There usually are several nights with frost each season, and overhead sprinkler irrigation usually is used to protect plants from freeze damage (1). Plastic tunnels may provide an alternative means to control Botrytis fruit rot and to protect plants from frost, but this cultural system also may result in more powdery mildew on susceptible cultivars $(6,10)$.

The objectives of this study were to compare epidemics of Botrytis fruit rot and powdery mildew on fruit between field and tunnel production systems, evaluate marketable yields of two major cultivars under these two production systems, and evaluate the potential of large plastic tunnels for control of Botrytis fruit rot. A preliminary report has been published (22).

\section{MATERIALS AND METHODS}

Experiments were conducted at the University of Florida Gulf Coast Research and Education Center at Dover, FL, during the 1998-99 and 1999-2000 seasons. Prior to transplanting each season, a 6:2:8 (N-P-K) starter fertilizer was broadcast applied to 
the ground at $570 \mathrm{~kg} \mathrm{ha}^{-1}$, and beds were raised and fumigated with a mixture of methyl bromide and chloropicrin (98:2, vol:vol) at $400 \mathrm{~kg} \mathrm{ha}^{-1}$. The experimental design was split plot with three replications. Treatments included two main plots (open field and plastic tunnel) and four subplots, including factorial combinations of two cultivars (Camarosa and Sweet Charlie) and two captan application schedules. Captan schedules included 7- and 14day intervals of $3.3 \mathrm{~kg}$ of active ingredient $\mathrm{ha}^{-1}$ in 1998-99. Because very low levels of Botrytis fruit rot developed in tunnels in 1998-99, an untreated control was included in 1999-2000 and captan was tested only on the 7-day schedule. Each subplot was
$12 \mathrm{~m}$ long and consisted of two rows on a single bed. Tunnels $(15 \times 5 \times 3 \mathrm{~m}$, each $)$ were established to span four beds and covered with clear, plastic UV-absorbing film (Dura Green, Mount Dora, FL). Plastic side panels were opened and closed manually to facilitate air movement, temperature control, and pollinator access. Weather stations (Adcon Telemetry, Boca Raton, FL) were set up in the field and in one tunnel to monitor temperature, relative humidity, leaf wetness, and rainfall.

Plants of strawberry cultivars Sweet Charlie and Camarosa, from a Canadian nursery, were set on 16 October, 1998, and 15 October, 1999. Plants were overheadsprinkler irrigated $10 \mathrm{~h}$ daily for 10 to 14 days for establishment and then drip irrigated and maintained according to recommendations for commercial production (1). Fruit were harvested twice weekly 30 November, 1998, to 29 March, 1999, in the first season, and 3 December, 1999, to 16 March, 2000, or 23 March, 2000, for Sweet Charlie or Camarosa, respectively, in the second season. The number of marketable fruit and culls, weight of marketable fruit, and numbers of Botrytis- and powdery mildew-diseased fruit were determined. The severity of powdery mildew on leaves was assessed on 12 March, 1999, and 27 January, 2000. Ten plants from each bed (subplot) were selected randomly for disease assessment. The severity of pow-
Botrytis fruit rot
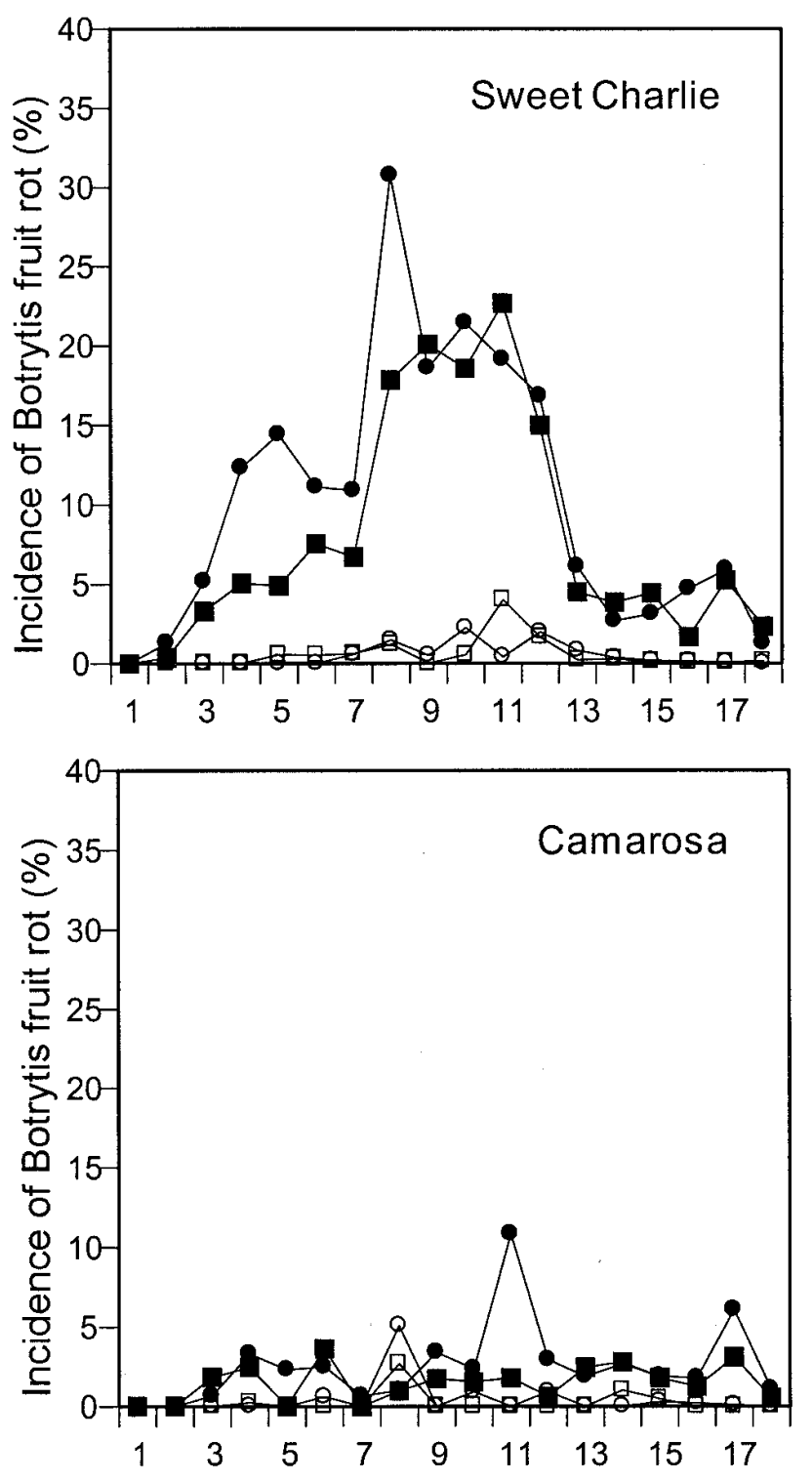

Powdery mildew on fruit
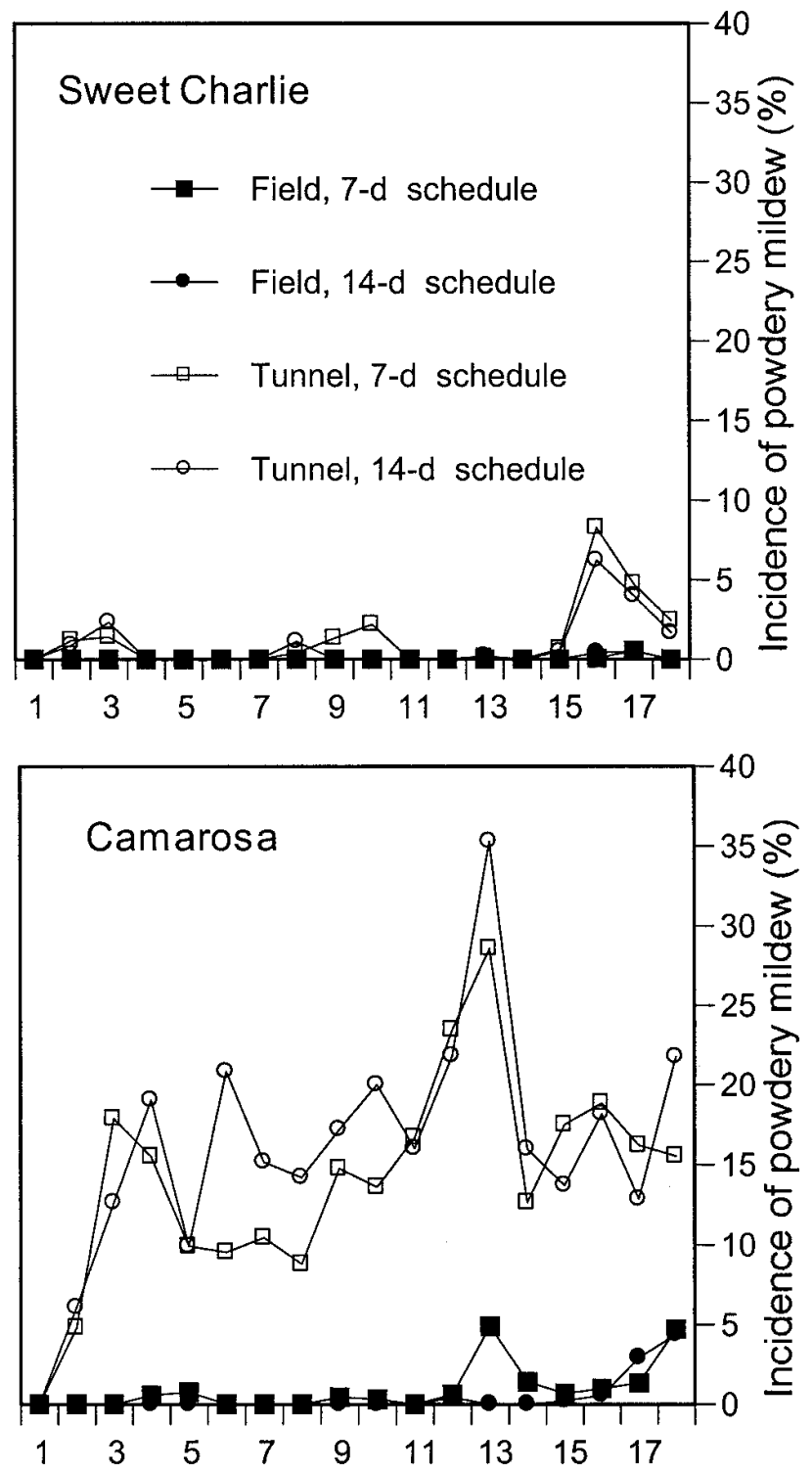

Harvest week

Fig. 1. Weekly incidence of Botrytis fruit rot and powdery mildew on fruit of strawberry cultivars Camarosa and Sweet Charlie grown in the field and in large plastic tunnels in the $1998-99$ season. Two captan spray programs, with 7 - and 14 -day schedules at the rate of $3.3 \mathrm{~kg}$ of active ingredient ha ${ }^{-1}$, were included. 
dery mildew was determined with the use of a 0 to 5 rating scale in which $0=$ no visible symptoms, $1=$ less than $10 \%$ foliage diseased, $2=10$ to $25 \%$ foliage diseased, $3=25$ to $50 \%$ foliage diseased, $4=$ 50 to $75 \%$ foliage diseased, and $5=$ more than $75 \%$ foliage diseased.

Statistical analysis was performed with SAS, release 6.12 (SAS Institute, Cary, NC). Analysis of variance was performed for the cumulative incidence of Botrytis fruit rot and powdery mildew on fruit and marketable yield for the early-period (harvests from the first 8 weeks), late-period (all harvests after the first 8 weeks), and whole-season data. The incidence of Botrytis fruit rot and powdery mildew on fruit were calculated as the percentage of diseased fruit in the total number of fruit harvested during a period. Incidence data were arcsine-square root transformed prior to analysis. Marketable yield was cumulative from all harvests during each period. Where the interactions of main plot and subplot were significant, analysis of variance also was performed separately for each main plot (field and tunnel). Mean comparisons were made with Fisher's protected least significant difference test $(P \leq$ 0.05 ). The incidence of Botrytis fruit and powdery mildew fruit were calculated from two harvests each week. Weekly disease incidence was plotted against time (harvest week) to compare disease progress curves between treatments. Analysis of variance also was performed on the foliar severity of powdery mildew.

\section{RESULTS}

Botrytis fruit rot. Botrytis fruit rot epidemics were severe in the field but not in tunnels during both seasons (Figs. 1 and 2). Cultural systems significantly affected the development of Botrytis fruit rot during early-, late-, and whole-season periods in 1998-99 and 1999-2000 (Table 1). In the field, the incidence of Botrytis fruit rot during all three periods ranged from 1.5 to $2.6 \%$ on Camarosa and 5.9 to $9.2 \%$ on Sweet Charlie in 1998-99, and 2.7 to $4.3 \%$ on Camarosa and 16.5 to $18.8 \%$ on Sweet

\section{Botrytis fruit rot}
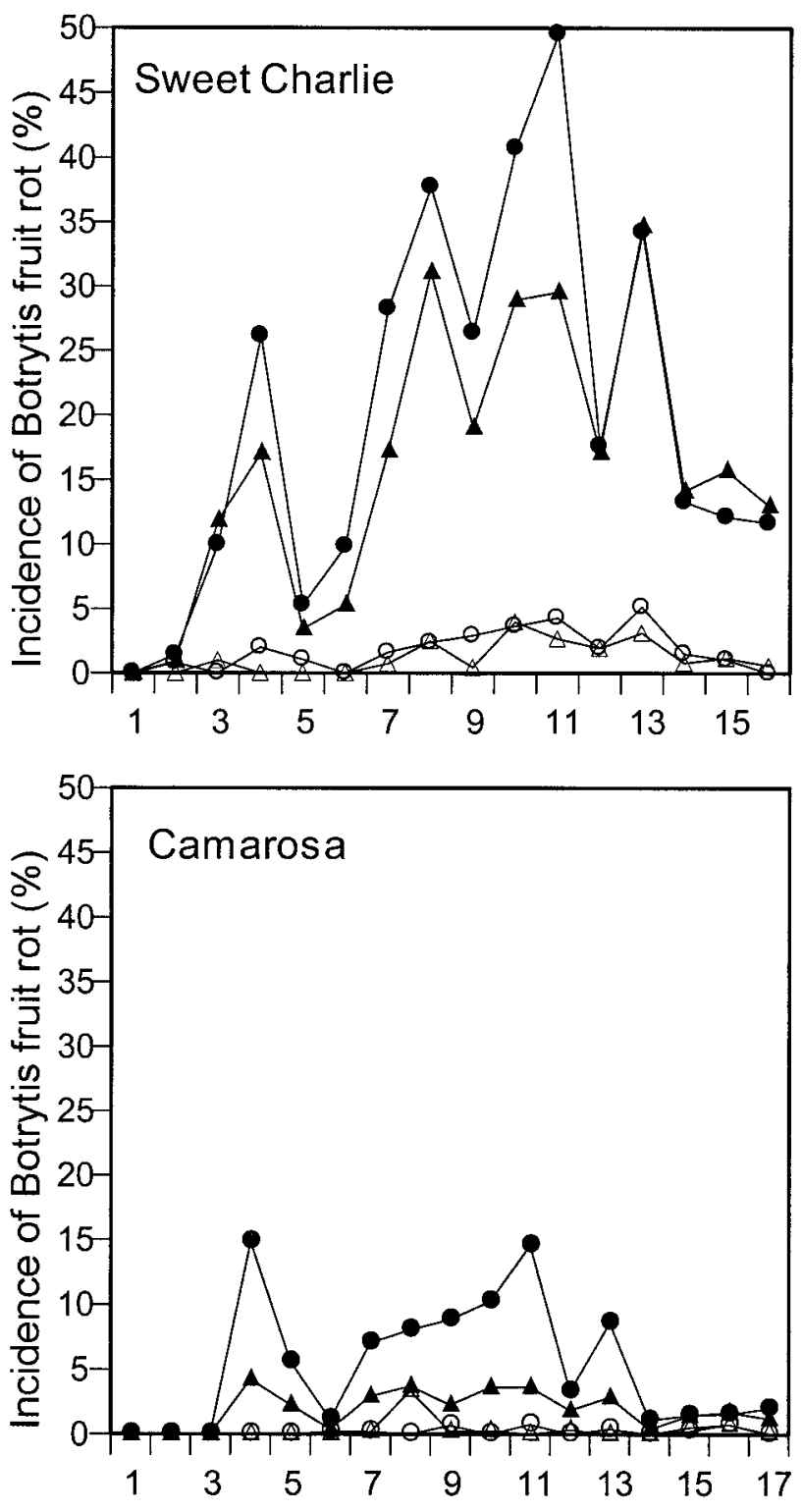

Powdery mildew on fruit
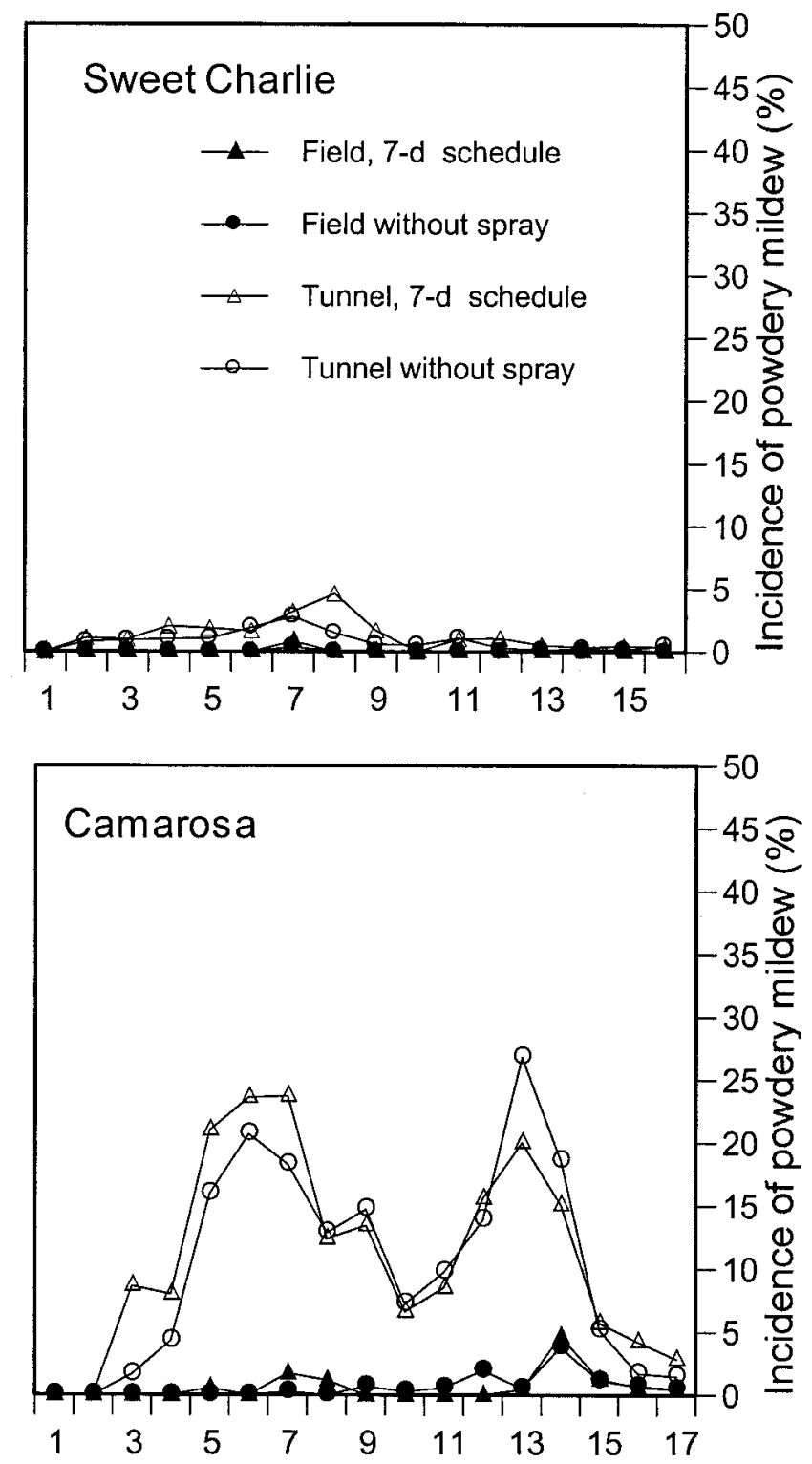

Harvest week

Fig. 2. Weekly incidence of Botrytis fruit rot and powdery mildew on fruit of strawberry cultivars Camarosa and Sweet Charlie grown in the field and in large plastic tunnels in the $1999-2000$ season. Two captan spray programs, with a 7 -day schedule at the rate of $3.3 \mathrm{~kg}$ of active ingredient ha ${ }^{-1}$, and an untreated control were included. 
Table 1. Analysis of variance describing effects of culture (field and plastic tunnel), cultivar (Camarosa and Sweet Charlie), and captan on cumulative incidence of Botrytis fruit rot and powdery mildew on fruit and marketable yield for three different periods during 1998-99 and 1999-2000

\begin{tabular}{|c|c|c|c|c|c|c|c|c|c|}
\hline \multirow[b]{2}{*}{ Season-variation source } & \multicolumn{3}{|c|}{ Early period ${ }^{\mathrm{x}}$} & \multicolumn{3}{|c|}{ Late period } & \multicolumn{3}{|c|}{ Whole season } \\
\hline & df & $\mathbf{M S}^{\mathbf{y}}$ & $P>F$ & df & MS & $P>F$ & df & MS & $P>F$ \\
\hline \multicolumn{10}{|c|}{ 1998-99-Botrytis fruit rot incidence } \\
\hline Block & 2 & 0.0025 & 0.3938 & 2 & 0.0050 & 0.0041 & 2 & 0.0038 & 0.0115 \\
\hline Culture & 1 & 0.1575 & 0.0162 & 1 & 0.1501 & 0.0010 & 1 & 0.1407 & 0.0017 \\
\hline Block $\times$ culture $\left(\right.$ error $\left._{a}\right)$ & 2 & 0.0026 & & 2 & 0.0002 & & 2 & 0.0002 & \\
\hline Cultivar & 1 & 0.0465 & 0.0010 & 1 & 0.0203 & 0.0001 & 1 & 0.0207 & 0.0001 \\
\hline Culture $\times$ cultivar & 1 & 0.0509 & 0.0007 & 1 & 0.0046 & 0.0140 & 1 & 0.0119 & 0.0006 \\
\hline Captan $^{z}$ & 1 & 0.0048 & 0.1924 & 1 & 0.0017 & 0.1011 & 1 & 0.0029 & 0.0435 \\
\hline Culture $\times$ captan & 1 & 0.0011 & 0.5136 & 1 & 0.0009 & 0.2127 & 1 & 0.0005 & 0.3690 \\
\hline Cultivar $\times$ captan & 1 & 0.0011 & 0.5129 & 1 & 0.0014 & 0.1350 & 1 & 0.0012 & 0.1751 \\
\hline Culture $\times$ cultivar $\times$ captan & 1 & 0.0036 & 0.2537 & 1 & 0.0007 & 0.2966 & 1 & 0.0000 & 0.9004 \\
\hline Error $_{b}$ & 12 & 0.0025 & & 12 & 0.0012 & & 12 & 0.0005 & \\
\hline \multicolumn{10}{|c|}{ Powdery mildew incidence on fruit } \\
\hline Block & 2 & 0.0006 & 0.7612 & 2 & 0.0093 & 0.0146 & 2 & 0.0073 & 0.0237 \\
\hline Culture & 1 & 0.2664 & 0.0111 & 1 & 0.2517 & 0.0022 & 1 & 0.2425 & 0.0005 \\
\hline Block $\times$ culture $\left(\right.$ error $\left._{\mathrm{a}}\right)$ & 2 & 0.0030 & & 2 & 0.0005 & & 2 & 0.0001 & \\
\hline Cultivar & 1 & 0.1351 & 0.0001 & 1 & 0.2170 & 0.0001 & 1 & 0.1995 & 0.0001 \\
\hline Culture $\times$ cultivar & 1 & 0.1129 & 0.0001 & 1 & 0.0470 & 0.0001 & 1 & 0.0505 & 0.0001 \\
\hline Captan & 1 & 0.0001 & 0.8060 & 1 & 0.0000 & 0.9645 & 1 & 0.0000 & 0.9598 \\
\hline Culture $\times$ captan & 1 & 0.0018 & 0.3777 & 1 & 0.0004 & 0.6210 & 1 & 0.0001 & 0.7680 \\
\hline Cultivar $\times$ captan & 1 & 0.0000 & 0.9557 & 1 & 0.0000 & 0.9335 & 1 & 0.0000 & 0.9180 \\
\hline Culture $\times$ cultivar $\times$ captan & 1 & 0.0012 & 0.4844 & 1 & 0.0007 & 0.4918 & 1 & 0.0009 & 0.4342 \\
\hline Error $_{\mathrm{b}}$ & 12 & 0.0022 & & 12 & 0.0015 & & 12 & 0.0014 & \\
\hline \multicolumn{10}{|l|}{ Marketable yield } \\
\hline Block & 2 & $2.19 \mathrm{E}+06$ & 0.0166 & 2 & $1.04 \mathrm{E}+07$ & 0.1062 & 2 & $2.20 \mathrm{E}+07$ & 0.0476 \\
\hline Culture & 1 & $3.50 \mathrm{E}+05$ & 0.0315 & 1 & $3.61 \mathrm{E}+07$ & 0.1104 & 1 & $2.94 \mathrm{E}+07$ & 0.1407 \\
\hline Block $\times$ culture $\left(\right.$ error $\left._{\mathrm{a}}\right)$ & 2 & $1.15 \mathrm{E}+04$ & & 2 & $4.76 \mathrm{E}+06$ & & 2 & $5.20 \mathrm{E}+06$ & \\
\hline Cultivar & 1 & $4.32 \mathrm{E}+05$ & 0.3027 & 1 & $2.84 \mathrm{E}+07$ & 0.0182 & 1 & $3.59 \mathrm{E}+07$ & 0.0258 \\
\hline Culture $\times$ cultivar & 1 & $3.71 \mathrm{E}+06$ & 0.0083 & 1 & $1.09 \mathrm{E}+08$ & 0.0002 & 1 & $1.53 \mathrm{E}+08$ & 0.0002 \\
\hline Captan & 1 & $9.65 E+04$ & 0.6199 & 1 & $2.44 \mathrm{E}+05$ & 0.8043 & 1 & $6.48 \mathrm{E}+05$ & 0.7385 \\
\hline Culture $\times$ captan & 1 & $2.45 \mathrm{E}+04$ & 0.8017 & 1 & $3.62 \mathrm{E}+05$ & 0.7633 & 1 & $5.75 \mathrm{E}+05$ & 0.7532 \\
\hline Cultivar $\times$ captan & 1 & $2.14 \mathrm{E}+06$ & 0.0336 & 1 & $1.38 \mathrm{E}+06$ & 0.5577 & 1 & $6.97 \mathrm{E}+06$ & 0.2845 \\
\hline Culture $\times$ cultivar $\times$ captan & 1 & $9.67 \mathrm{E}+05$ & 0.1329 & 1 & $9.67 \mathrm{E}+05$ & 0.8728 & 1 & $4.41 \mathrm{E}+05$ & 0.7828 \\
\hline Error $_{\mathrm{b}}$ & 12 & $3.72 \mathrm{E}+05$ & & 12 & $1.02 \mathrm{E}+05$ & & 12 & $5.55 \mathrm{E}+06$ & \\
\hline \multicolumn{10}{|c|}{ 1999-2000-Botrytis fruit rot incidence } \\
\hline Block & 2 & 0.0047 & 0.0976 & 2 & 0.0036 & 0.0782 & 2 & 0.0039 & 0.0512 \\
\hline Culture & 1 & 0.3374 & 0.0049 & 1 & 0.2629 & 0.0023 & 1 & 0.2768 & 0.0014 \\
\hline Block $\times$ culture $\left(\right.$ error $\left._{a}\right)$ & 2 & 0.0017 & & 2 & 0.0006 & & 2 & 0.0004 & \\
\hline Cultivar & 1 & 0.0933 & 0.0001 & 1 & 0.2022 & 0.0001 & 1 & 0.1718 & 0.0001 \\
\hline Culture $\times$ cultivar & 1 & 0.0474 & 0.0002 & 1 & 0.0614 & 0.0001 & 1 & 0.0594 & 0.0001 \\
\hline Captan & 1 & 0.0075 & 0.0544 & 1 & 0.0019 & 0.2118 & 1 & 0.0027 & 0.1316 \\
\hline Culture $\times$ captan & 1 & 0.0157 & 0.0095 & 1 & 0.0001 & 0.7311 & 1 & 0.0014 & 0.2598 \\
\hline Cultivar $\times$ captan & 1 & 0.0009 & 0.4524 & 1 & 0.0010 & 0.3625 & 1 & 0.0004 & 0.5611 \\
\hline Culture $\times$ cultivar $\times$ captan & 1 & 0.0040 & 0.1447 & 1 & 0.0036 & 0.1010 & 1 & 0.0039 & 0.0743 \\
\hline Error $_{\mathrm{b}}$ & 12 & 0.0016 & & 12 & 0.0011 & & 12 & 0.0010 & \\
\hline \multicolumn{10}{|c|}{ Powdery mildew incidence on fruit } \\
\hline Block & 2 & 0.0015 & 0.1679 & 2 & 0.0002 & 0.2656 & 2 & 0.0002 & 0.3293 \\
\hline Culture & 1 & 0.3549 & 0.0007 & 1 & 0.0708 & 0.0086 & 1 & 0.1293 & 0.0017 \\
\hline Block $\times$ culture $\left(\right.$ error $\left._{a}\right)$ & 2 & 0.0003 & 0.7181 & 2 & 0.0006 & & 2 & 0.0002 & 0.3627 \\
\hline Cultivar & 1 & 0.1530 & 0.0001 & 1 & 0.1137 & 0.0001 & 1 & 0.1300 & 0.0001 \\
\hline Culture $\times$ cultivar & 1 & 0.0975 & 0.0001 & 1 & 0.0151 & 0.0001 & 1 & 0.0297 & 0.0001 \\
\hline Captan & 1 & 0.0086 & 0.0051 & 1 & 0.0001 & 0.3848 & 1 & 0.0011 & 0.0356 \\
\hline Culture $\times$ captan & 1 & 0.0000 & 0.9919 & 1 & 0.0007 & 0.0457 & 1 & 0.0008 & 0.0580 \\
\hline Cultivar $\times$ captan & 1 & 0.0019 & 0.1276 & 1 & 0.0000 & 0.6421 & 1 & 0.0000 & 0.7224 \\
\hline Culture $\times$ cultivar $\times$ captan & 1 & 0.0011 & 0.2339 & 1 & 0.0000 & 0.6111 & 1 & 0.0000 & 0.9477 \\
\hline Error $_{\mathrm{b}}$ & 12 & 0.0007 & & 12 & 0.0002 & & 12 & 0.0002 & \\
\hline \multicolumn{10}{|l|}{ Marketable yield } \\
\hline Block & 2 & $5.36 \mathrm{E}+06$ & 0.0005 & 2 & $1.39 \mathrm{E}+07$ & 0.0206 & 2 & $2.22 E+07$ & 0.0102 \\
\hline Culture & 1 & $8.62 \mathrm{E}+04$ & 0.8658 & 1 & $2.71 \mathrm{E}+07$ & 0.0993 & 1 & $2.41 \mathrm{E}+07$ & 0.2119 \\
\hline Block $\times$ culture $\left(\right.$ error $\left._{a}\right)$ & 2 & $2.35 \mathrm{E}+06$ & & 2 & $3.15 \mathrm{E}+06$ & & 2 & $7.35 E+06$ & \\
\hline Cultivar & 1 & $5.24 \mathrm{E}+07$ & 0.0001 & 1 & $2.16 \mathrm{E}+08$ & 0.0001 & 1 & $4.81 \mathrm{E}+08$ & 0.0001 \\
\hline Culture $\times$ cultivar & 1 & $5.76 \mathrm{E}+06$ & 0.0015 & 1 & $1.29 \mathrm{E}+08$ & 0.0001 & 1 & $1.89 \mathrm{E}+08$ & 0.0001 \\
\hline Captan & 1 & $1.31 \mathrm{E}+06$ & 0.0748 & 1 & $1.69 \mathrm{E}+06$ & 0.4311 & 1 & $2.43 E+04$ & 0.9324 \\
\hline Culture $\times$ captan & 1 & $4.94 \mathrm{E}+05$ & 0.2543 & 1 & $1.48 \mathrm{E}+07$ & 0.0328 & 1 & $2.07 \mathrm{E}+07$ & 0.0263 \\
\hline Cultivar $\times$ captan & 1 & $3.07 \mathrm{E}+04$ & 0.7705 & 1 & $1.33 \mathrm{E}+05$ & 0.8231 & 1 & $2.92 \mathrm{E}+05$ & 0.7690 \\
\hline Culture $\times$ cultivar $\times$ captan & 1 & $1.01 \mathrm{E}+03$ & 0.9576 & 1 & $1.37 \mathrm{E}+01$ & 0.9982 & 1 & $7.91 \mathrm{E}+02$ & 0.9878 \\
\hline Error $_{b}$ & 12 & $3.44 \mathrm{E}+05$ & & 12 & $2.55 \mathrm{E}+06$ & & 12 & $3.23 \mathrm{E}+06$ & \\
\hline
\end{tabular}

${ }^{\mathrm{x}}$ Early period is the first 8 weeks of harvests and the late period is for all harvests after the first 8 weeks of each season. Whole-season period includes all harvests for each season. Analysis of variance was performed on arcsine-square root-transformed data.

y Mean square.

${ }^{z}$ Captan treatment included two spray programs, with 7- and 14-day schedules at $3.3 \mathrm{~kg}$ per active ingredient ha ${ }^{-1}$ in the $1998-99$ season. In the 1999 2000 season, captan treatments were changed to include the 7-day schedule and an untreated control. 
Charlie in 1999-2000 (Table 2). In tunnels, the incidence of Botrytis fruit rot was less than 1 and 2\% in 1998-99 and 1999-2000, respectively.

Cultivars and the interaction of cultural systems and cultivars significantly affected the incidence of Botrytis fruit rot during early-, late-, and whole-season periods in both seasons, indicating that cultivar effects on Botrytis fruit rot depend on the cultural system (Tables 1 and 2). The incidence of Botrytis fruit rot in the field was significantly higher on Sweet Charlie than on Camarosa during all three periods in both seasons. In contrast, the incidence of the disease in tunnels was not significantly different between cultivars, except during the late- and whole-season periods in 19992000. The incidence of Botrytis fruit rot on Sweet Charlie in tunnels was reduced by 97, 93, and 94\% in 1998-99, and 95, 90, and $91 \%$ in 1999-2000 compared with those in the field for the early-, late-, and whole-season periods, respectively. The incidence of Botrytis fruit rot on Camarosa in tunnels also was reduced by 57 to $90 \%$ compared with those in the field during all three periods (Table 2).

There were no significant differences in the incidence of Botrytis fruit rot between the 7- and 14-day captan schedules during the early-, late-, and whole-season periods in the field and tunnels in 1998-99 (Table 2). In 1999-2000, the incidence of Botrytis fruit rot was significantly lower in the 7day captan schedule than in the untreated control during the early period in the field and during the late- and whole-season periods in tunnels. The incidence of Botrytis fruit rot in the untreated control in tunnels was reduced by $89 \%$ compared with the 7-day captan schedule in the field.

Powdery mildew. Severe epidemics of powdery mildew developed only in tunnels during both seasons (Figs. 1 and 2). The cultural system, cultivar, and cultural system-cultivar interaction significantly affected the incidence of powdery mildew on

Table 2. Cumulative Botrytis fruit rot incidence and marketable yield for different cultural systems (field and tunnel), cultivars (Camarosa and Sweet Charlie), or captan treatments (7- or 14-day schedule or no captan) from three periods during 1998-99 and 1999-2000

\begin{tabular}{|c|c|c|c|c|c|c|}
\hline \multirow[b]{2}{*}{ Culture-cultivar or captan } & \multicolumn{3}{|c|}{ 1998-99 Season } & \multicolumn{3}{|c|}{ 1999-2000 Season } \\
\hline & Early period ${ }^{u}$ & Late period & Whole season & Early period & Late period & Whole season \\
\hline \multicolumn{7}{|l|}{ Botrytis fruit rot incidence $(\%)^{\mathrm{v}}$} \\
\hline Field-Camarosa & $1.49 \mathrm{~b}^{\mathrm{w}}$ & $2.56 \mathrm{~b}$ & $2.33 \mathrm{~b}$ & $4.28 \mathrm{~b}$ & $2.72 \mathrm{~b}$ & $3.05 \mathrm{~b}$ \\
\hline Field-Sweet Charlie & $9.15 \mathrm{a}$ & $5.86 \mathrm{a}$ & $6.39 \mathrm{a}$ & $16.51 \mathrm{a}$ & $18.75 \mathrm{a}$ & $18.27 \mathrm{a}$ \\
\hline Tunnel-Camarosa & $0.64 \mathrm{a}$ & $0.11 \mathrm{a}$ & $0.24 \mathrm{a}$ & $0.47 \mathrm{a}$ & $0.31 \mathrm{~b}$ & $0.35 \mathrm{~b}$ \\
\hline Tunnel-Sweet Charlie & $0.29 \mathrm{a}$ & $0.39 \mathrm{a}$ & $0.37 \mathrm{a}$ & $0.85 \mathrm{a}$ & $1.93 \mathrm{a}$ & $1.66 \mathrm{a}$ \\
\hline \multicolumn{7}{|l|}{ Powdery mildew on fruit $(\%)^{\mathrm{x}}$} \\
\hline Field-Camarosa & $0.09 \mathrm{a}$ & $1.83 \mathrm{a}$ & $1.48 \mathrm{a}$ & $0.40 \mathrm{a}$ & $0.84 \mathrm{a}$ & $0.74 \mathrm{a}$ \\
\hline Field-Sweet Charlie & $0.00 \mathrm{a}$ & $0.12 \mathrm{~b}$ & $0.10 \mathrm{~b}$ & $0.08 \mathrm{a}$ & $0.01 \mathrm{~b}$ & $0.02 \mathrm{~b}$ \\
\hline Tunnel-Camarosa & $12.81 \mathrm{a}$ & $16.73 \mathrm{a}$ & $15.75 \mathrm{a}$ & $16.63 \mathrm{a}$ & $6.15 \mathrm{a}$ & $8.91 \mathrm{a}$ \\
\hline Tunnel-Sweet Charlie & $0.61 \mathrm{~b}$ & $2.34 \mathrm{~b}$ & $2.04 \mathrm{~b}$ & $1.84 \mathrm{~b}$ & $0.39 \mathrm{~b}$ & $0.75 \mathrm{~b}$ \\
\hline \multicolumn{7}{|l|}{ Marketable yield (kg/ha) } \\
\hline Field-Camarosa & $3,479 \mathrm{a}$ & 17,168 a & $20,647 \mathrm{a}$ & $8,594 \mathrm{a}$ & $23,627 \mathrm{a}$ & $32,221 \mathrm{~b}$ \\
\hline Field-Sweet Charlie & $2,961 \mathrm{a}$ & $15,074 \mathrm{a}$ & $18,035 \mathrm{a}$ & $4,660 \mathrm{~b}$ & $12,996 \mathrm{~b}$ & $17,656 \mathrm{a}$ \\
\hline Tunnel-Camarosa & $2,934 \mathrm{~b}$ & $10,442 \mathrm{~b}$ & $13,376 \mathrm{~b}$ & $7,734 \mathrm{a}$ & $16,873 \mathrm{a}$ & $24,607 \mathrm{a}$ \\
\hline Tunnel-Sweet Charlie & $3,989 \mathrm{a}$ & $16,892 \mathrm{a}$ & 20,881 a & $5,759 \mathrm{~b}$ & $15,503 \mathrm{a}$ & $21,262 b$ \\
\hline \multicolumn{7}{|l|}{ Botrytis fruit rot incidence $(\%)$} \\
\hline Field-No captan ${ }^{\mathrm{y}}$ & $\mathrm{ND}^{\mathrm{z}}$ & ND & ND & $12.59 \mathrm{a}$ & $10.91 \mathrm{a}$ & $11.26 \mathrm{a}$ \\
\hline Field-7-day schedule & $4.15 \mathrm{a}$ & $3.72 \mathrm{a}$ & $3.79 \mathrm{a}$ & $8.19 \mathrm{~b}$ & $10.57 \mathrm{a}$ & $10.06 \mathrm{a}$ \\
\hline Field-14-day schedule & $6.49 \mathrm{a}$ & $4.71 \mathrm{a}$ & $4.92 \mathrm{a}$ & ND & ND & ND \\
\hline Tunnel-No captan & ND & ND & ND & $0.58 \mathrm{a}$ & $1.33 \mathrm{a}$ & $1.14 \mathrm{a}$ \\
\hline Tunnel-7-day schedule & $0.39 \mathrm{a}$ & $0.21 \mathrm{a}$ & $0.25 \mathrm{a}$ & $0.74 \mathrm{a}$ & $0.91 \mathrm{~b}$ & $0.87 \mathrm{~b}$ \\
\hline Tunnel-14-day schedule & $0.55 \mathrm{a}$ & $0.29 \mathrm{a}$ & $0.37 \mathrm{a}$ & ND & ND & ND \\
\hline \multicolumn{7}{|l|}{ Powdery mildew on fruit $(\%)$} \\
\hline Field-No captan & ND & ND & ND & $0.43 \mathrm{a}$ & $0.39 \mathrm{a}$ & $0.39 \mathrm{a}$ \\
\hline Field-7-d schedule & $0.09 \mathrm{a}$ & $0.93 \mathrm{a}$ & $0.77 \mathrm{a}$ & $0.06 \mathrm{~b}$ & $0.46 \mathrm{a}$ & $0.37 \mathrm{a}$ \\
\hline Field-14-d schedule & $0.00 \mathrm{a}$ & $1.02 \mathrm{a}$ & $0.81 \mathrm{a}$ & ND & ND & ND \\
\hline Tunnel-No captan & ND & ND & ND & $10.23 \mathrm{a}$ & $3.47 \mathrm{a}$ & $5.33 \mathrm{a}$ \\
\hline Tunnel-7-day schedule & $6.08 \mathrm{a}$ & $9.70 \mathrm{a}$ & $8.90 \mathrm{a}$ & $8.24 \mathrm{a}$ & $3.07 \mathrm{a}$ & $4.33 \mathrm{~b}$ \\
\hline Tunnel-14-d schedule & $7.34 \mathrm{a}$ & $9.37 \mathrm{a}$ & $8.89 \mathrm{a}$ & ND & ND & ND \\
\hline \multicolumn{7}{|l|}{ Marketable yield (kg/ha) } \\
\hline Field-No captan & ND & ND & ND & $7,004 \mathrm{a}$ & $18,832 \mathrm{a}$ & $25,836 \mathrm{a}$ \\
\hline Field-7-day schedule & $3,125 \mathrm{a}$ & $15,897 \mathrm{a}$ & $19,022 \mathrm{a}$ & $6,249 \mathrm{a}$ & $17,792 \mathrm{a}$ & $24,041 \mathrm{a}$ \\
\hline Field-14-day schedule & $3,316 \mathrm{a}$ & $16,345 \mathrm{a}$ & $19,661 \mathrm{a}$ & ND & ND & ND \\
\hline Tunnel-No captan & ND & ND & ND & $6,837 \mathrm{a}$ & $15,137 \mathrm{~b}$ & $21,974 \mathrm{~b}$ \\
\hline Tunnel-7-day schedule & $3,431 \mathrm{a}$ & $13,689 \mathrm{a}$ & $17,120 \mathrm{a}$ & $6,656 \mathrm{a}$ & $17,239 \mathrm{a}$ & $23,895 \mathrm{a}$ \\
\hline Tunnel-14-day schedule & $3,494 \mathrm{a}$ & $13,645 \mathrm{a}$ & $17,139 \mathrm{a}$ & ND & ND & ND \\
\hline
\end{tabular}

u Early period is the first 8 weeks of harvests, late period is for all harvests after the first 8 weeks of each season, and whole season includes all harvests of that season.

${ }^{v}$ Botrytis fruit rot incidence values are expressed as the percentage of fruit harvested with Botrytis rot in the total fruit harvested during the period.

${ }^{w}$ Means followed by the same letter within a column in each section are not significantly different as determined by Fishers protected least significant difference test $(P \leq 0.05)$.

$\mathrm{x}$ Powdery mildew incidence values are expressed as the percentage of fruit harvested with powdery mildew in the total fruit harvested during the period.

y Captan treatment included two spray programs, with 7- and 14-day schedules at $3.3 \mathrm{~kg}$ of active ingredient ha ${ }^{-1}$ in the $1998-99$ season. In the $1999-2000$ season, the captan treatments were changed to include the 7-day schedule and an untreated control.

${ }^{\mathrm{z}} \mathrm{ND}=$ not determined . 
fruit during the early-, late-, and wholeseason periods in both seasons (Table 1). Tunnel culture was conducive to the development of powdery mildew on fruit. The incidence of powdery mildew on Camarosa fruit was 12.8 to $16.7 \%$ in $1998-99$ and 6.2 to $16.6 \%$ in $1999-2000$ in tunnels during all three periods. Additionally, it was 141-, 8-, and 10-fold higher in tunnels than in the field in 1998-99 and 41-, 6-, and 11-fold higher in tunnels than in the field in 1999-2000 for the early-, late-, and whole-season periods, respectively (Table 2). Sweet Charlie had a consistently lower incidence of powdery mildew ( 0 to $2.3 \%$ ) than Camarosa in the field and tunnels in both seasons, except during the early period in the field (Table 2). Captan schedules did not affect the incidence of powdery mildew on fruit, except during the early period in the field, and in the whole-season period in tunnels in 19992000, when the incidence of powdery mildew on fruit was significantly higher with the 7-day captan schedule than in the untreated control (Table 2).

The foliar severity of powdery mildew was assessed for both seasons. Analysis of variance indicated that the foliar severity of powdery mildew differed between the field and tunnels in 1998-99 $(P=0.0538)$ and $1999-2000(P=0.0891)$ and that the cultivar and cultural system-cultivar interaction significantly affected the foliar severity (Table 3 ). The foliar severity of powdery mildew was significantly higher on Camarosa than on Sweet Charlie in both seasons, except there was no significant difference in foliar severity of powdery mildew between the two cultivars in tunnels in 1999-2000.

Marketable yield. Significant differences in marketable yield between strawberries treated on the field or tunnels $(P=$ 0.0315 ) occurred during the early period in 1998-99 (Table 1). Yield differences also were evident $(P=0.0993)$ between cultural systems during the late period in 19992000. Marketable yields were significantly different between cultivars during early-, late-, and whole-season periods in both seasons, except during the early period in 1998-99 (Tables 1 and 2). Significant cultural system-cultivar interactions occurred during all three periods in both seasons, indicating that yield differences resulting from disease depend upon cultural systems. The yield of Sweet Charlie in tunnels during the early period increased 35 and $24 \%$ compared with the field in 1998-99 and 1999-2000, respectively. The yield of Camarosa in tunnels during the early period, however, decreased 19 and $11 \%$ compared with the field in 1998-99 and 19992000, respectively (Table 2).

Marketable yield differences between the 7- and 14-day captan schedules were not significant in the field and tunnels in 1998-99. In 1999-2000, the yields of fungicide-treated plants in the late- and wholeseason periods were significantly higher than those of the untreated plants. The early-season yield of plants in tunnels, however, was not affected significantly by fungicide treatment. Additionally, the yield from plants grown in the open field was not affected by fungicide treatment, regardless of the harvest period (Table 2).

Microclimate. Temperature, relative humidity, leaf-wetness duration, and precipitation in the field and tunnel from the 1998-99 season are illustrated in Figures 3 and 4. Because of equipment failure, leafwetness duration data in tunnels were not available for the second season. Shorter leaf-wetness periods and higher temperatures were associated with the tunnel compared with the field. In 1998-99, during the early period (weather data recorded 5 November, 1998, to 22 January, 1999), there were 77 days, with an average of $12.9 \mathrm{~h}$ of dew in the field. In contrast, there were only 30 days, with an average of $4.5 \mathrm{~h}$ of dew in the tunnel. The average temperatures were 19.3 and $20.4^{\circ} \mathrm{C}$, and the average relative humidities were 85.8 and $78.9 \%$ in the field and tunnel, respectively. During the late period (weather data recorded 23 January, 1999, to 29 March, 1999), there were 67 days with an average of $11.7 \mathrm{~h}$ of dew in the field compared with 26 days with an average of $5.2 \mathrm{~h}$ of dew in the tunnel. The average temperatures were 18.2 and $19.7^{\circ} \mathrm{C}$, and the average relative humidities were 78.5 and $70.8 \%$ in the field and tunnel, respectively. In the field, there was 16.3 and $14.2 \mathrm{~cm}$ of rainfall during the early and late periods, respectively. In 1999-2000, the weather differences between the tunnel and field were

Table 3. Foliar severity of powdery mildew in 1998-99 and 1999-2000

\begin{tabular}{llcc}
\hline & & \multicolumn{2}{c}{ Foliar severity of powdery mildew $^{\mathbf{y}}$} \\
\cline { 3 - 4 } Cultural system & \multicolumn{1}{c}{ Cultivar } & $\mathbf{1 9 9 8 - 9 9}$ & $\mathbf{1 9 9 9 - 2 0 0 0}$ \\
\hline Field & Camarosa & $2.02 \mathrm{a}^{\mathrm{z}}$ & $1.75 \mathrm{a}$ \\
& Sweet Charlie & $0.65 \mathrm{~b}$ & $1.20 \mathrm{~b}$ \\
\multirow{2}{*}{ Tunnel } & & $3.12 \mathrm{a}$ & $1.18 \mathrm{a}$ \\
& Camarosa & $0.63 \mathrm{~b}$ & $1.00 \mathrm{a}$ \\
\hline
\end{tabular}

${ }^{\mathrm{y}}$ Foliar severity of powdery mildew was determined by a $0-5$ rating scale in which $0=$ no visible symptom, $1=$ less than $10 \%$ foliage diseased, $2=10$ to $25 \%$ foliage diseased, $3=25-50 \%$ foliage diseased, $4=50-75 \%$ foliage diseased, and $5=$ more than $75 \%$ foliage diseased.

${ }^{\mathrm{z}}$ Means followed by the same letter within a column in each section are not significantly different as determined by Fishers protected least significant difference test $(P \leq 0.05)$. similar to those in 1998-99 (data not shown).

\section{DISCUSSION}

In this study, we observed much less Botrytis fruit rot in the tunnels than in the field, especially on Sweet Charlie, a highly susceptible cultivar. The early-season yield was higher in tunnels than in the field only for Sweet Charlie.

This study is part of our efforts to develop alternative production systems or modify cultural practices for Botrytis fruit rot control. Wider within-row plant spacing has been shown to reduce Botrytis fruit rot by 26 to $42 \%$ compared with narrower spacings (9), and the removal of senescent foliage slightly reduced Botrytis fruit rot (11). These methods can supplement chemical control but are ineffective to replace fungicides to control Botrytis fruit rot. The present study documents the successful control of Botrytis fruit rot with large plastic tunnels as an alternative production system. Tunnel culture provides better control of Botrytis fruit rot than the conventional production system, i.e., an open field with standard fungicide applications. Thus, it has the potential to serve as a nonchemical alternative for the control of Botrytis fruit rot.

The dramatic reduction of Botrytis fruit rot in tunnels can be attributed to a few possible mechanisms. Shorter periods of leaf wetness were associated consistently with the tunnel compared with the field. The frequency of days with leaf wetness was over $60 \%$ less in the tunnel than in the field in 1998-99. The infection of flower and fruit by $B$. cinerea and subsequent sporulation are favored by extended periods of leaf wetness $(2,17,19,20,21)$. The incidence of infection by conidia of $B$. cinerea at 15 to $25^{\circ} \mathrm{C}$ increases from near zero to $90 \%$ as the leaf-wetness duration increases from 6 to $24 \mathrm{~h}$ (19). Therefore, shorter periods of leaf wetness inside tunnels would reduce fruit infection by $B$. cinerea.

Conidia of $B$. cinerea are dispersed mainly by splashing rain and wind (19). Precipitation plays an important role in spore production and the dispersal of many pathogens, including $B$. cinerea. Frequent rains during the strawberry fruiting season would increase the splash dispersal of inoculum, resulting in more infections on fruit in the field than in the tunnel (19). Inside tunnels, plants were protected from rain and splash dispersal of inoculum.

Reduced light intensity in tunnels also might affect $B$. cinerea infection and spore production. Films absorbing near-UV radiation reduce spore production in vitro for $B$. cinerea and other pathogens (13) and provide a reduction in the incidence of Botrytis on tomato and cucumber grown in the greenhouse (4). The film used in the present study was a clear UV-absorbing film. Thus, it is possible that the infection 
and sporulation of $B$. cinerea was inhibited in tunnels.

In 1998-99, the 7-day captan schedule did not provide additional control of Botrytis fruit rot compared with the 14-day cap$\tan$ schedule in the field or tunnels. This might be the result of the relatively low disease pressure in the field in 1998-99. When disease pressure is low, small treatment effects are more difficult to separate. Because very low levels of Botrytis fruit rot developed inside the tunnels in 199899, only the 7-day captan schedule and an untreated control were evaluated in 19992000. Even though the 7-day captan schedule significantly reduced the incidence of
Botrytis in tunnels, the disease level was less than $2 \%$ in the untreated control. Thus, there seems to be no need to use fungicide to control Botrytis in tunnel systems. In 1999-2000, the 7-day captan schedule provided control of Botrytis during the early period in the field and the late period in tunnels but not the early period in tunnels and the late period in the field. The lack of differences in the incidence of Botrytis fruit rot observed between the 7-day captan schedule and the untreated control during the early period in the tunnels might be the result of very low levels of disease. The cause for the failure of disease control during the late period in the field is uncer- tain. One possible explanation is that increased rainfall during that period in the field may have reduced fungicide residues.

The development of powdery mildew is favored by low light intensity, moderate to high relative humidity without free moisture, and temperatures of approximately 15 to $27^{\circ} \mathrm{C}(5,10,12,14)$. In both seasons, environmental conditions in tunnels favored powdery mildew development, except at the end of the season (March) when temperatures apparently became too high. Surprisingly, the difference in the foliar severity of powdery mildew between the field and tunnels was not significant. In contrast, the incidence of powdery mildew
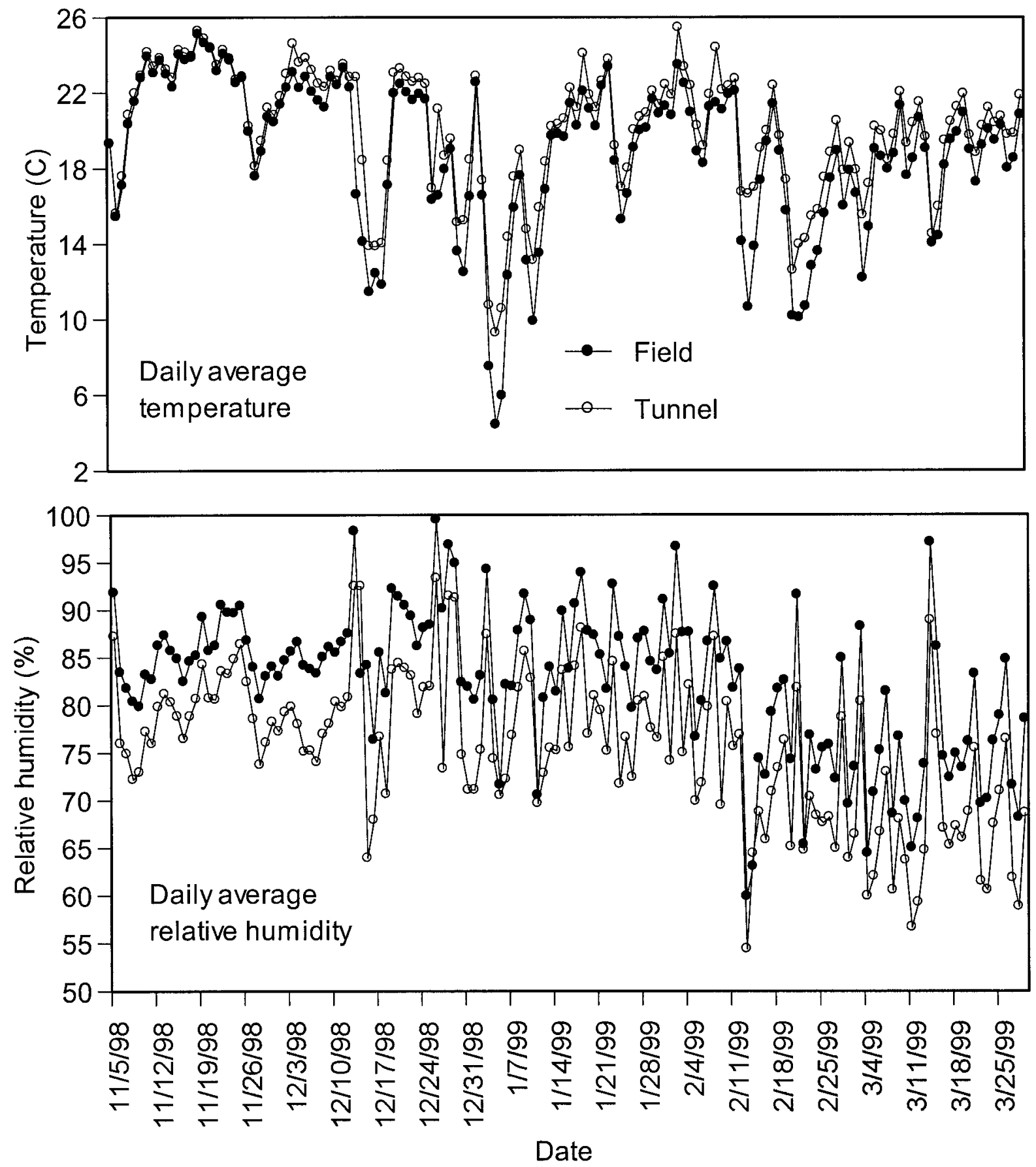

Fig. 3. Daily average temperatures and daily average relative humidities in the field and tunnel in the 1998-99 season. 
on fruit was much higher in tunnels than in the field. The conditions required for fruit and leaf infection might be different. Powdery mildew can be a limiting factor for strawberry fruit production in tunnels, although effective organic products such as sulfur or other labeled fungicides can provide good control of powdery mildew (8) or resistant cultivars such as Sweet Charlie, which in turn may reduce or eliminate the reliance on fungicides for powdery mildew control in tunnels.

High early-season marketable yields are very important to the profitability of producing strawberries because the market value of fruit in December and January can be four to five times greater than the market value later in the season. Temperature is an important factor affecting early production (18), and the higher early-season yield might be attributed to elevated temperatures in tunnels. Early-season production also depends upon the flowering and fruiting patterns of individual cultivars and their interactions with the environment. Sweet Charlie produces fruit earlier than Camarosa. In tunnels, a 24 to $35 \%$ increase of early production was observed on Sweet Charlie compared with the field. No marketable yield differences were observed between the 7- and 14-day captan schedules in 1998-99 and between the 7-day captan schedule and the untreated control during the early period in 1999-2000. This could be the result of a lack of differences in Botrytis fruit rot incidence among fungicide treatments during the corresponding periods.

In Florida, a calendar-based fungicide spray program with weekly applications of captan is the standard practice for commercial strawberry production. Such a program costs approximately $\$ 1,400 /$ ha (16). Even with standard fungicide applications, Botrytis fruit rot can still cause 10 to $15 \%$ losses of marketable yield on highly susceptible cultivars such as Sweet Charlie $(7,9)$. In this study, tunnel culture reduced the incidence of Botrytis fruit rot to less than $2 \%$, without fungicides. Thus, in addition to saving costs on fungicides, the use of tunnel culture could increase marketable yield compared with the standard conventional production system. During these experiments, yields of Sweet Charlie were 8 to $13 \%$ higher in tunnels than in the field, which adds up to $\$ 2,000$ to $\$ 3,250 /$ ha in farm gate revenue. The cost of building plastic tunnels with a metal frame is approximately $\$ 28,000 / \mathrm{ha}$, but the plastic
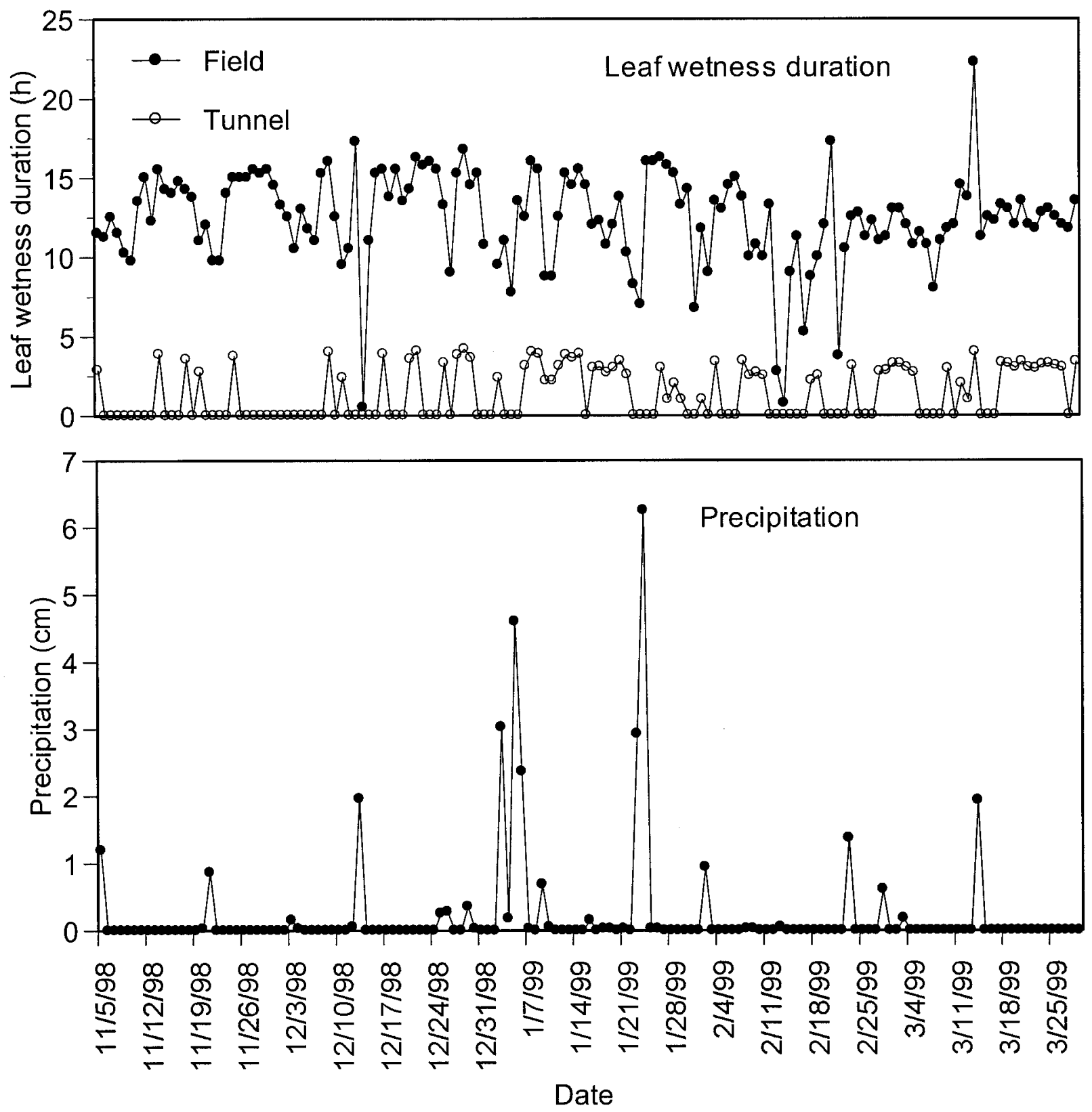

Fig. 4. Daily leaf-wetness durations and precipitation in the field and tunnel in the 1998-99 season (no precipitation observed in the tunnel). 
cover can be used for 2 to 3 years and then replaced at a cost of $\$ 8,000 /$ ha. Apparently, the economic feasibility of tunnel production in Florida is questionable as a result of high start-up costs. Additional restrictions on fungicide use as a result of food safety concerns and the reduced availability of water for freeze protection in the region may force changes in production practices in Florida, which could make tunnel culture an attractive alternative.

\section{ACKNOWLEDGMENTS}

We thank K. Burke, C. Manley, L. Smith, S. Staton, J. Sumler, A. Turgeau, and D. Wenzel for their valuable assistance during this study.

\section{LITERATURE CITED}

1. Albregts, E. E., and Howard, C. M. 1984. Strawberry Production in Florida. Univ. Fla. Inst. Food Agric. Sci. Bull. 841.

2. Bulger, M. A., Ellis, M. A., and Madden, L. V. 1987. Influence of temperature and wetness duration on infection of strawberry flowers by Botrytis cinerea and disease incidence of fruit originating from infected flowers. Phytopathology 77:1225-1230.

3. Hancock, J. F., and Simpson, D. 1995. Methods of extending the strawberry season in Europe. Hortic. Tech. 5:286-290.

4. Honda, Y., Toki, T., and Yunoki, T. 1977. Control of gray mold of greenhouse cucumber and tomato by inhibiting sporulation. Plant Dis. Rep. 61:1041-1044.

5. Jhooty, J. S., and McKeen, W. E. 1965. Studies on powdery mildew of strawberry caused by Sphaerotheca macularis. Phytopathology
55:281-285.

6. Jordan, V. W. L., and Hunter, T. 1972. The effects of glass cloche and coloured polyethylene tunnels on microclimate, growth, yield and disease severity of strawberry plants. J. Hortic. Sci. 47:419-426.

7. Legard, D. E., and Chandler, C. K. 1998. Evaluation of fungicides to control Botrytis fruit rot of strawberry, 1997. Fungicide Nematicide Tests 53:121.

8. Legard, D. E., Xiao, C. L., and Mertely, J. C. 2000. Evaluation of fungicides to control powdery mildew and Botrytis fruit rot of strawberry, 1999. Fungicide Nematicide Tests 55:130.

9. Legard, D. E., Xiao, C. L., Mertely, J. C., and Chandler, C. K. 2000. Effects of plant spacing and cultivar on incidence of Botrytis fruit rot in annual strawberry. Plant Dis. 84:531-538.

10. Mass, J. L. 1998. Compendium of Strawberry Diseases, 3rd ed. American Phytopathological Society, St. Paul, MN.

11. Mertely, J. C., Chandler, C. K., Xiao, C. L., and Legard, D. E. 2000. Comparison of sanitation and fungicides for management of Botrytis fruit rot of strawberry. Plant Dis. 84:1197-1202.

12. Nelson, M. D., Gubler, W. D., and Shaw, D. V. 1996. Relative resistance of 47 strawberry cultivars to powdery mildew in California greenhouse and field environments. Plant Dis. 80:326-328.

13. Nicot, P. C., Mermier, M., Vaissière, B. E., and Lagier, J. 1996. Differential spore production by Botrytis cinerea on agar medium and plant tissue under near-ultraviolet lightabsorbing polyethylene film. Plant Dis. 80:555-558.

14. Peries, O. S. 1962. Studies on strawberry mildew, caused by Sphaerotheca macularis (Wallr. ex Fries) Jaczewski, I: Biology of the fungus. Ann. Appl. Biol. 50:211-224.

15. Radajewska, B., and Dejwor, I. 1997. Yield and mean weight of fruit from six strawberry cultivars grown under unheated plastic tunnels over three years. Acta Hortic. 439:528531.

16. Smith, S. A., and Taylor, T. G. 1997. Production cost for selected vegetables in Florida. Univ. Fla. Coop. Ext. Serv. Circ. 1202:1-27.

17. Sosa-Alvarez, M., Madden, L. V., and Ellis, M. A. 1995. Effects of temperature and wetness duration on sporulation of Botrytis cinerea on strawberry leaf residues. Plant Dis. 79:609-615.

18. Strand, L. L. 1994. Integrated Pest Management for Strawberries: Publ. 3351. University of California, Division of Agriculture and Natural Resource, Oakland.

19. Sutton, J. C. 1998. Botrytis fruit rot (gray mold) and blossom blight. Pages 28-31 in Compendium of Strawberry Diseases, 3rd ed. J. L. Mass, ed. American Phytopathological Society, St. Paul, MN.

20. Sutton, J. C. 1990. Epidemiology and management of Botrytis leaf blight of onion and gray mold of strawberry: A comparative analysis. Can. J. Plant Pathol. 12:100-110.

21. Wilcox, W. F., and Seem, R. C. 1994. Relationship between strawberry gray mold incidence, environmental variables, and fungicide applications during different periods of the fruiting season. Phytopathology 84:264-270.

22. Xiao, C. L., Chandler, C. K., Price, J. F., and Legard, D. E. 1999. Comparative study on epidemics of strawberry fruit diseases under plastic tunnel and field production systems in Florida. (Abstr.) Phytopathology 89:S86. 